\title{
Antioxidant, Anti-diabetic, Anti-cholinesterase, and Nitric Oxide Inhibitory Activities of Fruiting Bodies of Agaricus brasiliensis
}

\author{
Ki Nam Yoon ${ }^{1}$, Hyung Seok Jang ${ }^{2}$, and Ga-Heon Jin ${ }^{3}$ \\ ${ }^{1}$ Department of Clinical Laboratory Science, Ansan University, Ansan 15651, Korea \\ ${ }^{2}$ Department of Pathology, Hanyang University Medical Center, Seoul 04763, Korea \\ ${ }^{3}$ Department of Ophthalmic Optics, Shinhan University, Uijeongbu 11644, Korea
}

\section{신령버섯 자실체 메탄올 추출물의 항산화, 항당뇨 및 Nitric Oxide의 저해 효과}

\author{
윤기남 ${ }^{1}$, 장형석 $^{2}$, 진가헌 $^{3}$ \\ ${ }^{1}$ 안산대학교 임상병리과, ${ }^{2}$ 한양대학교병원 병리과, ${ }^{3}$ 신한대학교 안경광학전공
}

\begin{abstract}
Agaricus brasiliensis, belonging to the family Agaricaceae of Agaricales, Basidiomycota, has been used for edible and medicinal purposes. This study was initiated to evaluate the antioxidant, anti-diabetic, and nitric oxide inhibitory activities of fruiting bodies of $A$. brasiliensis extracted with methanol. The HPLC analysis of phenolic compounds from the mushroom extracts identified 10 phenolic compounds including gallic acid, procatechuic acid, chlorogenic acid, (-)-epicatechin, vanillin, rutin hydrate, naringin, quercetin, formononetin, and biochanin-A. The free radical scavenging activities of methanol extract were lower than that of positive control, BHT. The chelating effects of methanol extract were significantly higher than those of the positive control, $\mathrm{BHT}$ at the all concentrations tested. The methanol extract exhibited the lower reducing power activities compared with the positive control at the $0.5 \sim 6.0 \mathrm{mg} / \mathrm{mL}$ concentration. The mushroom extract inhibited the $\alpha$-glucosidase activity by $54.48 \%$ and $78.43 \%$ at the 1.0 and $2.0 \mathrm{mg} / \mathrm{mL}$ while acarbose, the positive control, inhibited the $\alpha$-glucosidase activity by $51.77 \%$ and $81.81 \%$ at the same concentrations, respectively. Nitric oxide (NO) production in lipopolysaccahride (LPS) induced RAW 264.7 cells were inhibited by the methanol extracts in a concentration dependent manner. Therefore, it is concluded that fruiting bodies of $A$. brasiliensis contained natural antioxidant, anti-diabetic, and anti-inflammatory substances which can be useful for human health.
\end{abstract}

Keywords: Agaricus brasiliens, Anti-diabetes, Anti-inflammation, Antioxidant

This is an Open Access article distributed under the terms of the Creative Commons Attribution Non-Commercial License (http://creativecommons.org/licenses/by-nc/4.0) which permits unrestricted non-commercial use, distribution, and reproduction in any medium, provided the original work is properly cited.

Copyright @ 2015 The Korean Society for Clinical Laboratory Science. All rights reserved.
Corresponding author: Ki Nam Yoon Department of Clinical Laboratory Science, Ansan University, Ansan 15651, Korea Tel: 82-31-400-708

E-mail: kinam@ansan.ac.kr

Received: October 6, 2015

Revised: November 20, 2015

Accepted: November 23, 2015

\section{서 론}

최근 인구의 고령화와 각종 사회적인 스트레스, 그리고 서구적 으로 변한 식생활 습관으로 인해 암, 치매, 당뇨병 등의 성인병은 증
가 추세여서 현대의학이 지속적으로 발전함에도 아직도 성인병은 우리의 인류가 반드시 극복하고 해결해야 할 과제로 남아있다. 이 러한 어려운 문제를 해결하기 위해 생명과학, 약학, 의약 분야의 연 구자들은 천연물에서 추출한 물질을 이용해 부작용이 적고 효과가 
높은 의약품을 개발하기 위해 많은 노력을 기울이고 있다. 버섯은 곰팡이에 속하는 미생물로 분류학상으로는 담자균류와 일부의 자 낭균류에 속해있다. 지난 10 여 년 간 버섯을 대상으로 한 연구에서 버섯의 자실체에는 항산화, 항암, 항균, 항고혈압, 항당뇨, 항콜레 스테롤, 면역증강, 항치매, 항비만 등을 나타내는 다양한 생리활성 물질을 함유하고 있다는 것이 밝혀졌다. 특히 페놀성 화합물은 식 물계와 미생물계에 널리 분포되어 있는 2 차 대사산물의 한 종류로 다양한 분자량과 구조를 갖고 있으며 hydroxyl기를 갖고 있어서 거대분자인 단백질이나 효소에 강하게 결합하는 특성 때문에 항산 화, 항암, 항균, 항당뇨 등의 생리활성 효과를 나타낸다고 보고되어 있다(Prasad 등, 2005).

버섯에 함유된 생리활성 물질을 적절히 섭취하면 우리의 건강이 증진되고 또한 산업적으로 새로운 의약품을 개발할 수 있는 가능성 도 높아지고 있어 최근 이 분야의 연구가 활발하게 진행되고 있다 (Wasser와 Weis, 1999; Um 등, 2010).

신령버섯(Agaricus brasiliensis)은 담자균류(Basidiomycota) 의 주름버섯목(Agaricales) 주름버섯과(Agaricaceae), 주름버섯 속(Agaricus)에 속하는 버섯으로 브라질을 비롯한 남미와 북미 일 부 지역의 땅위에 군생하는 낙엽부후균으로 온도와 습도가 높아지 면 대량 발생하는 성질이 있어서 브라질 아마존 지역의 원주민들은 우기에 이 버섯을 대량으로 채취하여 식용으로 사용하고 있다. 최 근 외국의 연구지들이 신령버섯의 자실체에는 항균, 항암, 항산화, 항고지혈증 등을 나타내는 생리활성 물질이 함유되어 있어 건강에 좋은 식품으로 보고하면서 우리나라에서도 이 버섯의 균주를 외국 으로부터 도입하여 인공재배를 시작하고 있으나 국내에서는 아직 까지 이 버섯의 생리활성에 대한 연구는 많이 이루어지지 않고 있 는 실정이다(Mizuno, 2002; Carvajal 등, 2012). 따라서 본 연구에 서는 현재 한약재 시장에서 판매되고 있는 신령버섯의 자실체를 구 매하여 이를 건강식품으로 안전하게 이용할 수 있는지 그 가능성을 알아보기 위해 신령버섯의 자실체를 메탄올을 이용해 추출물을 만 든 뒤 그 추출물을 이용해 항산화, 항당뇨 및 nitric oxide에 대한 저 해 효과 실험을 수행하고 그 결과를 보고하는 바이다.

\section{재료 및 방법}

\section{1. 실험재료}

실험에 사용한 신령버섯의 자실체는 2014년 12월 서울에 소재 한 경동 한약재 시장에서 구입하여 인천대학교 생명과학부 “버섯 균주은행”의 동정을 받은 후 $45^{\circ} \mathrm{C}$ 의 건조기에서 48 시간 건조한 후 마쇄하여 분말로 만든 뒤 $-80^{\circ} \mathrm{C}$ 의 저온냉동고에 보관하면서 실험 에 사용하였다.

\section{2. 성분의 추출 및 분리}

Shim 등(2003)의 방법에 따라 건조한 신령버섯 자실체의 분말 에 $80 \%$ 메탄올을 이용해 성분을 추출하여 실험에 사용하였다. 즉, $50 \mathrm{~g}$ 의 신령버섯 자실체의 분말을 $80 \%$ 의 메탄올 용액(Duksan Pure Chemicals Co., Ansan, Korea) 1,000 mL에 침지하여 48 시 간 동안 상온에서 3회 추출하고 모은 후 No. 2 여과지(Avantec Toyo Co., Otowa, Japan)로 여과하고 $40^{\circ} \mathrm{C}$ 에서 Eyela cool aca ca N-1000 회전 감압농축기(Eyela Co., Tokyo, Japan)을 이용하 여 감압 농축하였다. 농축액내의 여분의 수분을 제거하기 위해 FDU-8612 동결건조기(Operon Co., Gyeonggi-do, Korea)를 이 용하여 메탄올 추출 분말을 얻었다.

\section{3. 페놀성 화합물의 분석}

High-performance liquid chromatography (HPLC)를 이용 하여 신령버섯 자실체 추출물의 페놀성 화합물 분석을 Kim 등 (2008)의 방법을 이용하여 분석하였다. 실험에는 Alliance $\mathrm{R}$ HPLC system 2695 (Waters Co., Milford, MA, USA)와 Waters 사 의 $2680, \mathrm{C} 18$ column $(4.6 \mathrm{~mm} \times 150 \mathrm{~mm}$ )과 $\mathrm{DAD}$ detector을 사 용하여 유속 $0.8 \mathrm{~mL} / \mathrm{min}$, 컬럼 온도 $20^{\circ} \mathrm{C}$, 주입량 $20 \mu \mathrm{L}$ 로 분석하 였다. 이동상은 $0.1 \%$ acetic acid가 포함된 증류수(A)와 $0.1 \%$ acetic acid가 포함된 acetonitrile (B)로 A: 92\% B: 8\%-A: 0\% B: $100 \%$ gradient조건으로 분석하였다. 페놀성 화합물의 detection wavelength 범위는 $280 \mathrm{~nm}$ 로 하였으며, 실험에는 총 20 종류의 standard phenolic compound를 사용했으며 시료에 함유된 페놀 성 화합물의 정성과 정량은 standard chemicals의 retention time 과 고유의 스펙트럼을 비교하는 프로그램을 이용하여 분석하였다.

\section{4. 세포배양}

실험에 사용한 생쥐의 대식세포인 RAW 264.7는 서울대학교의 한국세포주은행에서 분양받았으며 이 세포의 배양에는 Dulbecco's Modified Eagle's (DMEM) 배지와 Roswell Park Memorial Institute (RPMI) 배지를 각각 기본배지로 하여 10\% fetal bovine serum (FBS), $100 \mathrm{U} / \mathrm{mL}$ penicillin 및 $100 \mu \mathrm{g} / \mathrm{mL}$ streptomycin 을 첨가하여 조제하여 $37^{\circ} \mathrm{C}, 5 \%$ 의 $\mathrm{CO}_{2}$ 배양기에서 3 일 배양하였다.

\section{5. 버섯 추출물의 세포 독성}

신령버섯 자실체 추출물의 RAW 264.7 세포에 대한 세포독성은 Mosmann (1983)의 방법에 따라 수행하였다. 지수기에 도달한 세 포를 RPMI-1640 배지가 분주된 96 plate well에 $2 \times 10^{5} \mathrm{cell} / \mathrm{mL}$ 의 농도로 분주하고 24 시간 배양한 후, 배지의 상층액을 제거하고 
신령버섯 추출물을 $25,50,100,1,000,2,000 \mu \mathrm{g} / \mathrm{mL}$ 농도로 각각 의 배지에 $200 \mu \mathrm{L}$ 첨가하여 48 시간 동안 배양하였다. 배양 완료 후 상층액을 제거하고 각각의 well에 MTT 용액( $5 \mathrm{mg} / \mathrm{mL}$ in PBS) 10 $\mu \mathrm{L}$ 씩을 첨가하고, 다시 $37^{\circ} \mathrm{C}, 5 \%$ 의 $\mathrm{CO}_{2}$ 배양기에서 4 시간 동안 배 양하여 MTT를 환원시켰다. 3-(4,5-dimethylthiazol-2-yl)-2,5-diphenylyetrazolium bromide (MTT)의 환원에 의해 각각의 well 에 생성된 보라색의 formazan 결정은 $150 \mu \mathrm{L}$ 의 $\mathrm{DMSO}$ 로 녹여 SpectraMax 340PC microplate reader (Molecular Devices Co., California, USA)를 이용해 $540 \mathrm{~nm}$ 파장에서 흡광도를 측정 하여 추출물의 세포 독성을 계산하였다.

\section{DPPH 라디칼 소거 활성}

2,2-diphenyl-1-picrylhydrazyl (DPPH) 라디칼 소거활성은 Blois (1958)의 방법으로 측정하였다. 시료를 메탄올로 녹여 최종 농도가 $0.125,0.25,0.5,1.0,2.0 \mathrm{mg} / \mathrm{mL}$ 이 되도록 정량하여 96 well plate에 각각의 시료를 $100 \mu \mathrm{L}$ 를 주입하고. 동시에 $0.3 \mathrm{mM}$ $\mathrm{DPPH} 100 \mu \mathrm{L}$ 를 넣어 총량이 $200 \mu \mathrm{L}$ 가 되도록 하였다. 실온에서 10 분간 반응시킨 후 SpectraMax 340PC microplate reader (Molecular Devices Co., California, USA)를 이용해 $540 \mathrm{~nm}$ 파장 에서 흡광도를 측정하였다. DPPH 라디칼 소거 활성은 시료 용액의 첨가군과 무첨가군 사이의 흡광도 차이를 백분율로 나타내었다.

$\mathrm{DPPH}$ 라디칼 소거 활성(\%)=[1-(첨가군 흡광도/무첨가군 흡광

$$
\text { 도) } \times 100
$$

\section{7. 철 이온 제거 효과}

철 이온 제거능 실험은 Yena 등(2002)의 방법에 준하여 수행하 였다. 그 원리는 신령버섯 추출물의 항산화 성분에 의해 $\mathrm{Fe}^{2+}$ 이온 이 제거되어 더 이상 ferrozine- $\mathrm{Fe}^{2+}$ 복합체를 형성하지 못하는 것 을 기본으로 하여 측정하였다. 먼저 각각의 농도별로 버섯 추출물 을 준비 하였다. 버섯 추출물 $2.0 \mathrm{~mL}$ 에 $2 \mathrm{mM} \mathrm{FeCl}_{2}$ (Sigma Aldrich Co., St Louis, USA) $0.05 \mathrm{~mL}$ 를 혼합한 후 $5 \mathrm{mM}$ 의 ferrozine $0.2 \mathrm{~mL}$ 를 첨가하여 반응시킨 뒤 메탄올 $2.75 \mathrm{~mL}$ 를 가하 여 총용량이 $5 \mathrm{~mL}$ 가 되도록 하고 vortex mixer를 이용하여 강하게 진탕한 뒤 Optizen POP UV/VIS spectrophotometer (Mecasys Co., Daejeon, Korea)를 이용하여 $562 \mathrm{~nm}$ 에서 반응액의 흡광도 를 측정하여 아래의 계산식에 의해 철 이온 제거능을 계산하였다. 양성대조군으로는 Butylated hydroxytoluene (BHT)를 사용하였다.

Chelating effect on ferrous ions $(\%)=\left[\left(\mathrm{A}_{\text {control }}-\mathrm{A}_{\text {sample }}\right) /\right.$ $\left.\mathrm{A}_{\text {control }}\right] \times 100$

\section{8. 환원력 측정}

신령버섯 추출물의 환원력 활성에 대한 실험은 Gulcin 등 (2003)의 방법에 따라 수행하였다. 시료 $2.5 \mathrm{~mL}$ 에 sodium phosphate buffer (2.5 mL, $200 \mathrm{mM}, \mathrm{pH}$ 6.6)와 1\% potassium ferricyanide $(2.5 \mathrm{~mL})$ 를 혼합시킨 후 혼합물을 $50^{\circ} \mathrm{C}$ 에서 20 분 간 incubation한 뒤 trichloroacetic acid $(2.5 \mathrm{~mL}, 10 \%, \mathrm{w} / \mathrm{v})$ 를 첨가 하여 $650 \times \mathrm{g}$ 에서 10 분간 원심 분리하였다. 원심분리 한 상층액 5 $\mathrm{mL}$ 에 3차 증류수 $5 \mathrm{~mL}$ 와 $1 \%$ ferric chloride $1 \mathrm{~mL}$ 를 첨가한 후 Optizen POP UV/VIS spectrophotometer (Mecasys Co., Daejeon, Korea)를 이용하여 $700 \mathrm{~nm}$ 에서 흡광도를 측정하였다.

\section{9. $\alpha$-amylase 저해효과 측정}

$\alpha$-amylase 저해 활성 측정은 Worthington (1993)의 방법을 약 간 변형하여 수행하였다. 버섯추출물 $(0.125 \sim 2.0 \mathrm{mg} / \mathrm{mL})$ 을 20 $\mathrm{mM}$ 의 phosphate buffer (pH 6.9)에 녹여 $200 \mu \mathrm{L}$ 준비하고, 200 $\mu \mathrm{L}$ 의 $\alpha$-amylase 용액 $(0.5 \mathrm{U} / \mathrm{mL})$ 에 혼합하여 $25^{\circ} \mathrm{C}$ 에서 10 분간 선배양 후 $1 \%$ 녹말 용액 $200 \mu \mathrm{L}$ 를 첨가하고 $25^{\circ} \mathrm{C}$ 에서 30 분간 배양 하였다. 이 반응은 $1.0 \mathrm{~mL}$ 의 dinitrosalicylic acid reagent $(1.0 \mathrm{~g}$ of 3.5-dinitrosalicylic acid in $20 \mathrm{~mL}$ of $2 \mathrm{M} \mathrm{NaOH}+50 \mathrm{~mL}$ distilled water $+30 \mathrm{~g}$ potassium sodium tartrate tetrahydrate) 를 첨가하여 중지시킨 후 증류수에 녹여 $100 \mathrm{~mL}$ 의 용량이 되게 하 였다. 그 후 반응액이 들어있는 시험관을 water bath에서 5 분간 끓 인 후 상온이 될 때까지 식힌 후 분광광도계로 $540 \mathrm{~nm}$ 에서 흡광도 를 측정하여 $\alpha$-amylase의 활성이 억제되는 정도를 계산하였다. 대 조군은 완충액만을 사용하였으며, 양성대조군으로는 acarbose를 사용하였다.

\section{0. $\alpha$-glucosidase 저해효과 측정}

$\alpha$-glucosidase 저해 효과 실험은 Kim 등(2013)의 실험을 약간 변형하여 수행하였다. 추출물 $(0.125 \sim 2.0 \mathrm{mg} / \mathrm{mL})$ 을 $100 \mathrm{mM}$ 의 phosphate buffer (pH 6.9)에 녹여 $100 \mu \mathrm{L}$ 준비하고 $1.0 \mathrm{U} / \mathrm{mL}$ 의 $\alpha$-glucosidase 용액 $100 \mu \mathrm{L}$ 에 혼합하여 $37^{\circ} \mathrm{C}$ 에서 10 분간 배양 후 기질인 $5.0 \mathrm{mM}$ 의 $p$-nitrophenyl- $\alpha$-D-glucospyranoside (pNPG) 용액 $100 \mu \mathrm{L}$ 를 첨가하여 $37^{\circ} \mathrm{C}$ 에서 10 분간 반응시킨 후 이 반응액 $20 \mu \mathrm{L}$ 에 증류수를 첨가해 $1.0 \mathrm{~mL}$ 가 되게 희석한 후 $p \mathrm{NPG}$ 로부터 유리되어 나오는 반응 생성물인 p-nitrophenol을 Optizen POP UV/VIS spectrophotometer (Mecasys Co., Daejeon, Korea)를 이용하여 $405 \mathrm{~nm}$ 에서 $\alpha$-glucosidase의 저해 활성을 측정하였다. 양성대조군으로는 acarbose를 사용하였다. 


\section{Nitrite (NO) 생성 저해효과 측정}

$\mathrm{NO}$ 생성저해 효과는 면역이나 염증반응에 널리 사용되는 쥐의 대식세포인 RAW 264.7 세포를 Ryu 등(2003)의 방법을 이용해 측 정하였다. DMEM 배지가 들어있는 96 well plate에 쥐의 대식세포 인 RAW 264.7 세포를 $5 \times 10^{4}$ cell/well로 분주하고 12 시간 배양 후 신령버섯 추출물을 $0,0.5,1.0$ 및 $2.0 \mathrm{mg} / \mathrm{mL}$ 의 농도로 1 시간 전 처리 한 후 LPS를 $1 \mu \mathrm{g} / \mathrm{mL}$ 의 농도로 처리하고 24 시간 동안 배양 하였다. 배양 후 $100 \mu \mathrm{L}$ 의 상층액을 취한 후 동량의 Griess reagent (Sigma Co., St. Louis, MO, USA) $100 \mu \mathrm{L}$ 를 넣어 총량이 $200 \mu \mathrm{L}$ 가 되도록 하고 상온에서 10 분간 반응시킨 후 생성된 $\mathrm{NO}$ 의 양을 SpectraMax 340PC microplate reader (Molecular Devices Co., California, USA)를 이용하여 $540 \mathrm{~nm}$ 에서 흡광도를 측정하였 다. $\mathrm{NO}$ 의 농도는 아질산염의 표준 곡선을 이용해 구하였다.

\section{2. 통계 처리}

본 연구 결과는 SPSS version 20.0 (SPSS Inc., Chicago, IL, USA) 통계프로그램을 이용하여 분석하였다. 실험은 각 실험군 간 3 회 이상 반복 실험을 통하여 얻은 각각의 결과를 각 실험군의 평균 표준편차 $(m e a n \pm \mathrm{SD})$ 로 나타내었다. 각 시료 농도군에 대한 통계
적 유의검정은 대조군과 비교하여 Student's t-test 후, $p<0.05$ 수 준에서 통계적으로 유의성 있는 결과로 표시하였다.

\section{결 과}

\section{1. 추출물의 페놀성 화합물의 분석}

본 실험에서 신령버섯 자실체의 메탄올 추출물의 HPLC 페놀성 화합물 분석에 사용한 표준시약은 gallic acid, homogentisic, procatechuic acid, (+)-catechin, chlorogenic acid, (-)-epicatechin, (-)-epigallocatechin gallate, caffeic acid, vanillin, rutin hydrate, $\mathrm{p}$-coumaric acid, ferullic acid, naringin, myricetin, resveratrol, quercetin, naringenin, kaempferol, formononetin, biochanin-A 등 20 종류가 사용되었으며, HPLC 분석결과 분석된 페놀성 화합물은 Fig. 1과 같이 gallic acid, procatechuic acid, chlorogenic acid, (-)-epicatechin, vanillin, rutin hydrate, naringin, quercetin, formononetin, and biochanin-A 등 10종류가 분석되었고, 각각의 함량은 $12.67 \mu \mathrm{g} / \mathrm{g}$, $12.62 \mu \mathrm{g} / \mathrm{g}, 37.1 \mu \mathrm{g} / \mathrm{g}, 0.88 \mu \mathrm{g} / \mathrm{g}, 3.88 \mu \mathrm{g} / \mathrm{g}, 5.12 \mu \mathrm{g} / \mathrm{g}, 25.82$ $\mu \mathrm{g} / \mathrm{g}, 7.5 \mu \mathrm{g} / \mathrm{g}, 3.01 \mu \mathrm{g} / \mathrm{g}, 3.52 \mu \mathrm{g} / \mathrm{g}$ 이었으며 총 함량은 102.12 $\mu \mathrm{g} / \mathrm{g}$ 이었다(Fig. 1).
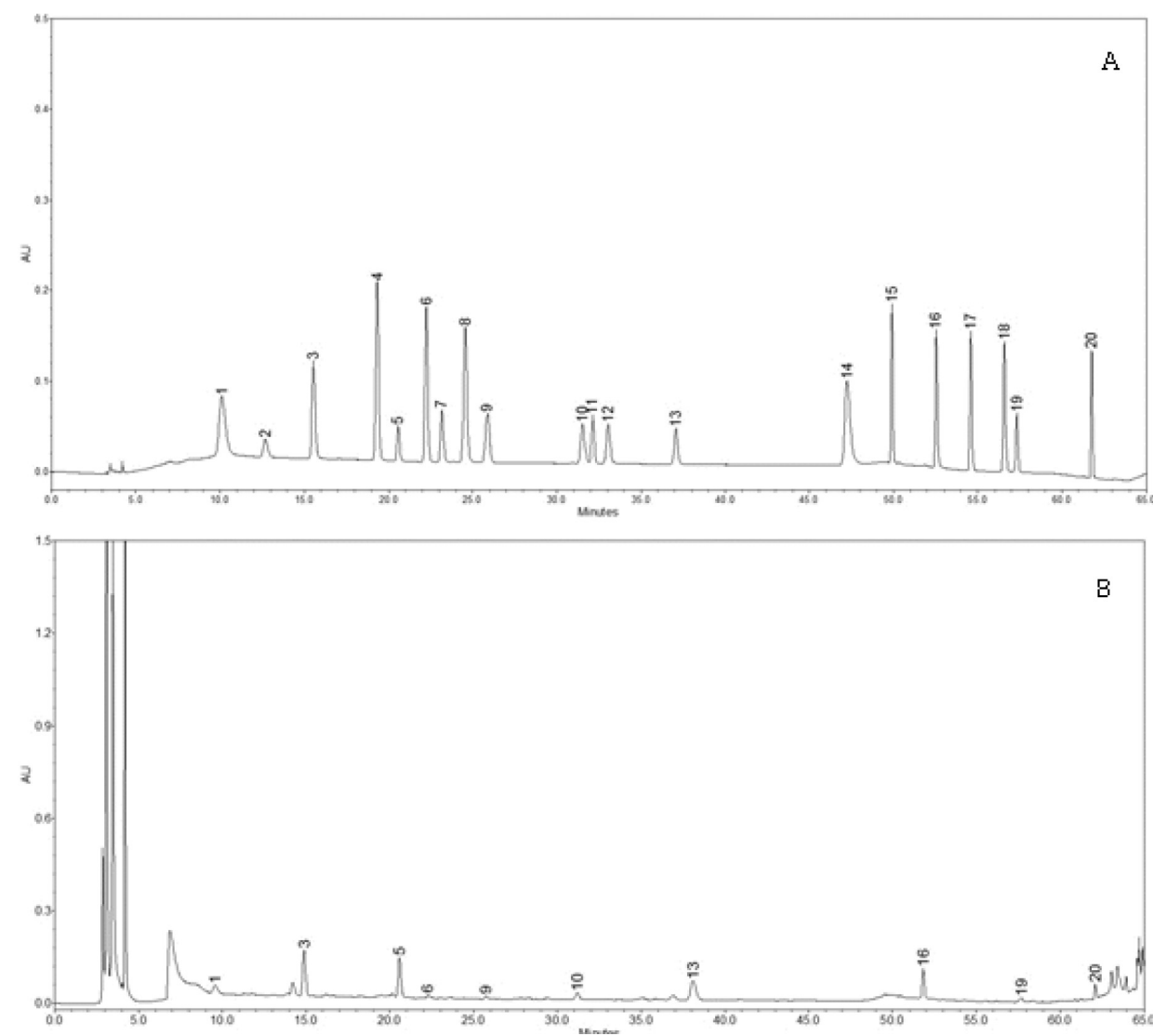

Fig. 1. HPLC analysis of phenolic compounds. (A) standard compounds; (B) Agaricus brasiliensi 1, gallic acid; 2, homonogentisic acid; 3, procatechuic acid; 4, (+)-catechin; 5, chlorogenic acid; 6, (-)-epicatechin; 7, (-)-epigallocatechin gallate; 8 , caffeic acid; 9, vanillin; 10, rutin hydrate; 11 , p-coumaric acid; 12 , ferullic acid; 13 , naringin; 14, myricetin; 15 , resveratrol; 16, quercetin; 17, naringenin; 18, kaempferol; 19, formonoentin; 20, biochanin-A. 


\section{2. 세포독성}

신령버섯의 자실체 추출물이 독성 효과를 나타내는지 알아보기 위해 신령버섯 자실체의 메탄올 추출물을 $25,50,100,1,000$ 및 $2,000 \mu \mathrm{g} / \mathrm{mL}$ 의 다양한 농도로 RAW 264.7 대식세포에 처리한 후 배양하여 MTT 방법을 이용해 세포의 생존율을 조사하였다. 실험 결과 RAW 264.7 세포는 메탄올 추출물 $25,50,100,1,000 \mu \mathrm{g} / \mathrm{mL}$ 의 농도에서 생존율이 각각 $138.33,143.46,141.24,109.24 \%$ 로 나타나 대조군에 생존율이 높아서 세포를 증식시키는 효과가 있는 것으로 나타났다. 그러나 $2,000 \mu \mathrm{g} / \mathrm{mL}$ 의 농도에서는 세포의 생존 율이 55.80\%로 나타나 신령버섯 자실체 추출물이 약간의 독성을 나타내는 것으로 사료되었다(Fig. 2).

\section{DPPH 라디칼 소거활성}

신령버섯 메탄올 추출물의 DPPH 소거활성은 $0.125 \mathrm{mg} / \mathrm{mL}$ 의 농도에서 $30.38 \%$ 로 나타나 양성대조군인 BHT의 $96.19 \%$ 에 비해 매우 낮았으나 1.0 과 $2.0 \mathrm{mg} / \mathrm{mL}$ 의 농도에서 라디칼 소거능이 각 각 $94.53 \%$ 와 $93.54 \%$ 로 증가되어 동일한 농도에서의 $\mathrm{BHT}$ 의 소거 활성에 비해 각각 $2.02 \%$ 와 $3.43 \%$ 의 낮은 소거 활성을 보였다(Fig. 3 ).

\section{4. 철 이온 제거 효과}

신령버섯 메탄올 추출물의 철 이온 제거활성 실험 결과, 추출물 의 농도 $0.125 \sim 2.0 \mathrm{mg} / \mathrm{mL}$ 범위의 모든 농도에서 양성 대조군으 로 사용한 BHT에 비해 철이온의 제거능이 높게 나타났다. 추출물 $1.0 \mathrm{mg} / \mathrm{mL}$ 와 $2.0 \mathrm{mg} / \mathrm{mL}$ 의 농도에서의 철 이온 제거 활성은 각각 90.95\%와 93.55\%로 나타나 양성대조군인 $\mathrm{BHT}$ 의 $60.45 \%$ 와 $69.84 \%$ 에 비해 철 이온 제거효과가 각각 $30.5 \%$ 와 $23.71 \%$ 높게 나

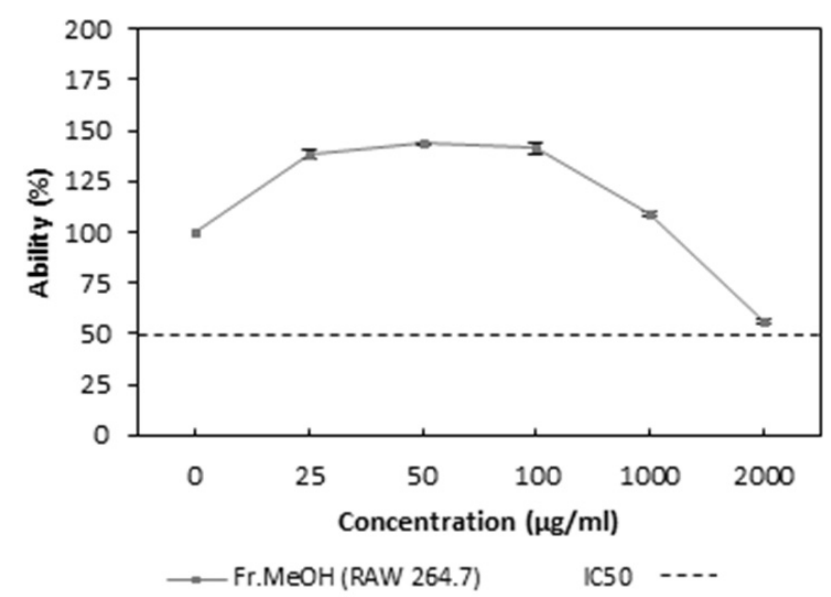

Fig. 2. In vitro cell cytotoxicity of methanol and hot water extracts from fruiting bodies of Agaricus brasiliensis against RAW 264.7 cells. Fr.MeOH, fraction extracted with $80 \%$ methanol; Fr.HW, fraction extracted with methanol.
타났다(Fig. 4).

\section{5. 환원력}

메탄올 추출물 $0.5 \mathrm{mg} / \mathrm{mL}$ 농도에서의 환원력은 0.304 이었고 이 농도에서의 BHT 환원력은 2.65로 높았으며 $6.0 \mathrm{mg} / \mathrm{mL}$ 의 농도 에서 버섯추출물의 환원력은 1.54 였고 BHT는 2.73 를 나타내 신령 버섯 자실체 추출물의 환원력은 동일한 농도에서 양성대조군에 비 해 매우 낮았다(Fig. 5). 따라서 신령버섯 메탄올 추출물의 환원력 은 실험에 사용한 $0.5 \sim 6.0 \mathrm{mg} / \mathrm{mL}$ 범위의 농도에서 양성대조군인 $\mathrm{BHT}$ 에 비해 모두 낮았다.

\section{6. $\alpha$-amylase 저해 효과}

메탄올 추출물은 $1.0 \mathrm{mg} / \mathrm{mL}$ 와 $2.0 \mathrm{mg} / \mathrm{mL}$ 의 농도에서 $\alpha$-amylase에 대한 저해 활성이 각각 $37.11 \%$ 와 $63.55 \%$ 로 나타나 서 양성대조군으로 사용한 acarbose의 동일 농도에서의 저해효과

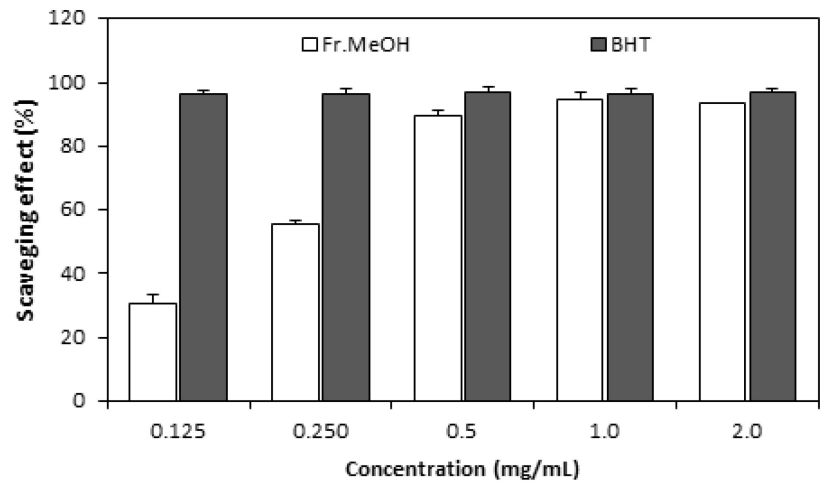

Fig. 3. Scavenging activities of methanol extract from fruiting bodies of Agaricus brasiliensis against 1,1-diphenyl-2-picrylhydrazyl. Fr.MeOH, fraction extracted with $80 \%$ methanol; $\mathrm{BHT}$, butylated hydroxytoluene. The values are expressed as means $\pm S D(n=3)$. ${ }^{\star \star *} p \leq 0.001 ;{ }^{*} p<0.05$ vs. BHT group.

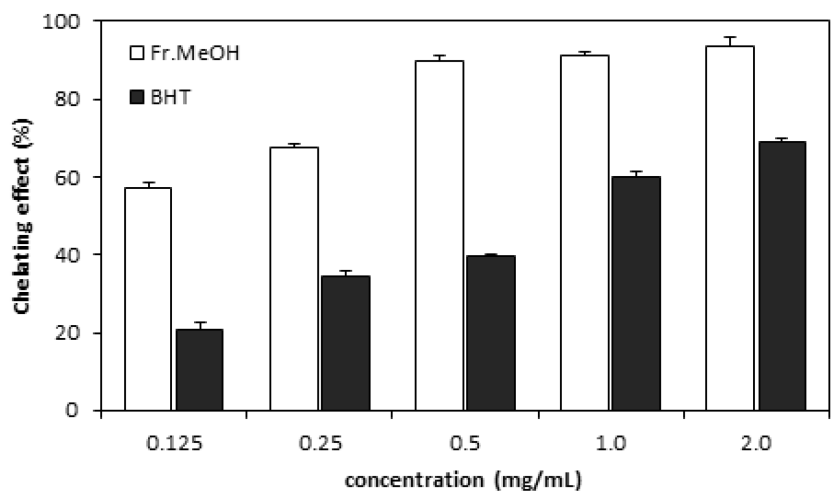

Fig. 4. Chelating effect of methanol from fruiting bodies of Agaricus brasiliensis. Fr.MeOH, fraction extracted with $80 \%$ methanol; BHT, butylated hydroxytoluene. The values are expressed as means \pm SD $(\mathrm{n}=3) .{ }^{* \star} p \leq 0.001$ vs. BHT group. 
83.69\%와 89.91\%에 비해 각각 저해 수치가 낮았다(Fig. 6).

\section{7. $\alpha$-glucosidase 저해 효과}

추출물 $1.0 \mathrm{mg} / \mathrm{mL}$ 와 $2.0 \mathrm{mg} / \mathrm{mL}$ 의 농도에서 $\alpha$-glucosidase 에 대한 저해 활성이 각각 $54.48 \%$ 와 $78.43 \%$ 로 나타났으며, 양성대 조군으로 사용한 acarbose는 동일한 농도에서 각각 $51.77 \%$ 와 $81.81 \%$ 의 저해 효과를 보였다(Fig. 7 ).

\section{Nitric oxide (NO) 생성 저해 효과}

RAW 264.7 대식세포에 신령버섯 자실체의 메탄올 추출물을 처 리한 후 염증 매개 물질인 lipopolysaccharide (LPS)를 처리하여 $\mathrm{RAW} 264.7$ 세포에서 $\mathrm{NO}$ 의 생성이 저해되는 실험을 수행하였다. 실험결과 LPS를 처리하지 않은 군에서 생성된 $\mathrm{NO}$ 의 농도는 6.79 $\mu \mathrm{M}$ 이었고 LPS만 처리한 군의 $\mathrm{NO}$ 농도는 $42.95 \mu \mathrm{M}$ 를 나타내 무 처리군에 비해 약 6.33 배 증가하였다. 그러나 메탄올 추출물을 1.0

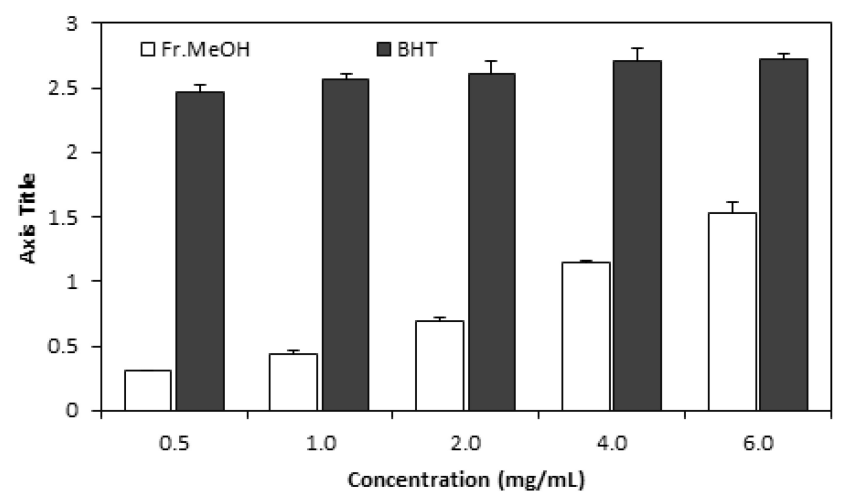

Fig. 5. Reducing power of methanol extract from fruiting bodies of Agaricus brasiliensis. Fr.MeOH, fraction extracted with $80 \%$ methanol; BHT, butylated hydroxyltoluene. The values are expressed as means $\pm S D(n=3)$. Values are expressed as mean \pm S.D $(n=3) .{ }^{* \star \star} p \leq 0.001$ vs. BHT group.

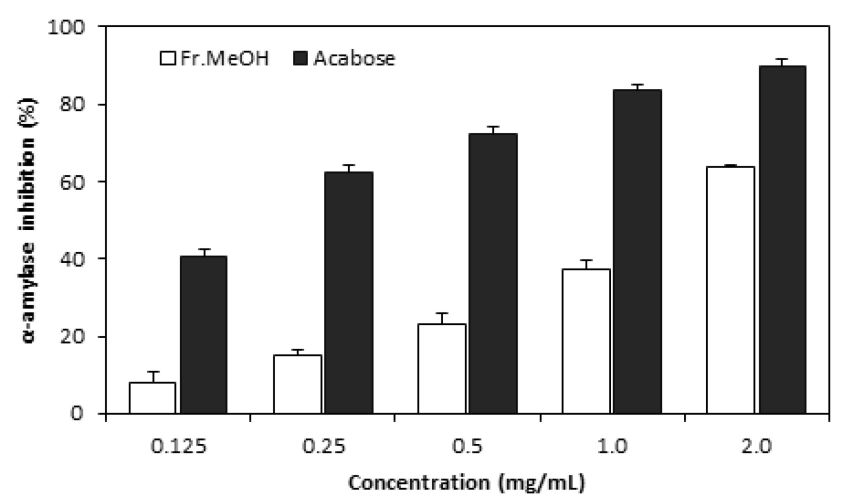

Fig. 6. $\alpha$-amylase inhibitory activity of methanol extract from fruiting bodies of Agaricus brasiliensis. Fr.MeOH, fraction extracted with $80 \%$ methanol. Acarbose used for positive control. The values are expressed as mean \pm S.D $(\mathrm{n}=3) .{ }^{* *} p \leq 0.001$ vs. Acarbose group. $\mathrm{mg} / \mathrm{mL}$ 와 $2.0 \mathrm{mg} / \mathrm{mL}$ 로 처리한 실험군의 $\mathrm{NO}$ 생성량은 각각 $26.32 \mathrm{mg} / \mathrm{mL}$ 과 $324.04 \mu \mathrm{M}$ 를 나타내 신령버섯 메탄올 추출물을 $1.0 \mathrm{mg} / \mathrm{mL}$ 와 $2.0 \mathrm{mg} / \mathrm{mL}$ 의 농도로 RAW 264.7 세포에 처리 했을 때 $\mathrm{NO}$ 생성량이 각각 $38.72 \%$ 와 $44.02 \%$ 감소시키는 효과가 있는 것으로 나타났다(Fig. 8).

\section{고 찰}

본 연구 결과 신령버섯의 자실체에서 추출된 $102.12 \mu \mathrm{g} / \mathrm{g}$ 의 페 놀성 화합물은 Lee 등(2014)이 능이버섯 자실체를 60\%의 에탄올 을 이용해 추출한 총 페놀성 화합물의 함량 $162.30 \mu \mathrm{g} / \mathrm{g}$ 에 것에 비 해서는 낮았으나 갈색먹물버섯 자실체에서 추출한 총 페놀성분 $26.58 \mu \mathrm{g} / \mathrm{g}$ 에 비해서 약 6.11 배 높은 것으로 나타났다.

또한 신령버섯 자실체 추출물을 안전하게 이용할 수 있는지 알

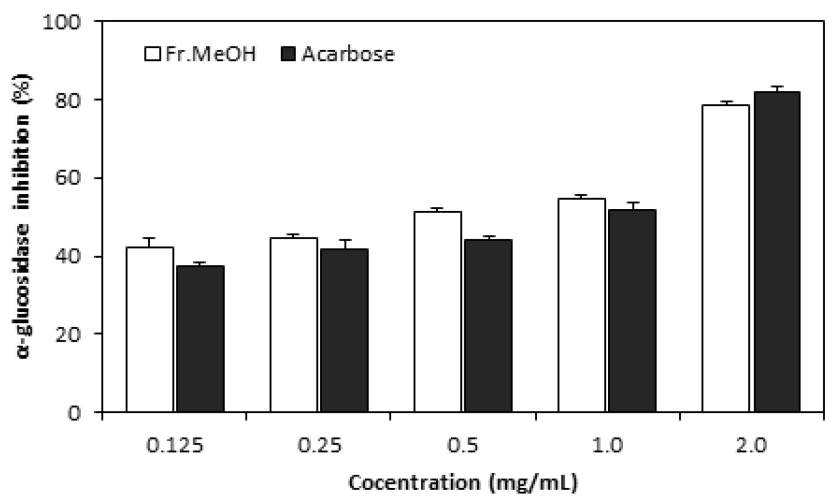

Fig. 7. $\alpha$-glucosidase inhibitory activity of methanol extract from fruiting bodies of Agaricus brasiliensis. Fr.MeOH, fraction extracted with $80 \%$ methanol. Acarbose used for positive control. The values are expressed as means \pm S.D ( $\mathrm{n}=3)$. ${ }^{\star} p<0.05$ vs. Acarbose group.

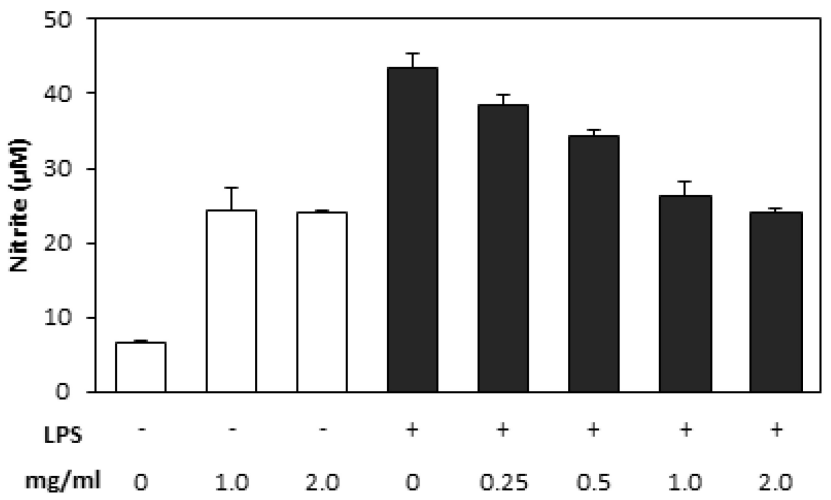

Fig. 8. Inhibitory effects of methanol extract from fruiting bodies of Agaricus brasiliensis on LPS-induced nitric oxide production in RAW 264.7 cells. Accumulated nitric oxide in the culture medium was determined by the Griess method. Fr.MeOH, fraction extracted with $80 \%$ methanol. The values are expressed as means \pm SD $(\mathrm{n}=3) .{ }^{* \star} p \leq 0.001 ;{ }^{* *} p \leq 0.01$ vs. Control group; ${ }^{\# \#} p \leq 0.001 ;{ }^{\# \#} \backslash p \leq$ 0.01 vs group treated with LPS. 
아보기 위해 신령버섯 자실체의 메탄올 추출물의 세포독성 실험을 수행하였다. 실험 결과 RAW 264.7 세포에 추출물을 $25 ~ 1,000$ $\mu \mathrm{g} / \mathrm{mL}$ 농도로 처리 했을 때 대조군에 비해 생존율이 높게 나타나 이 농도 범위에서는 세포 독성이 전혀 나타나지 않았고, 추출물의 농도를 2,000 $\mu \mathrm{g} / \mathrm{mL}$ 로 높였을 때 RAW 264.7 세포의 생존율이 $55.80 \%$ 로 나타났으며, 추출물의 농도를 증가시킴에 따라 농도 의 존적으로 RAW 264.7 세포의 생존율은 점차 감소하는 경향을 보였다. 신령버섯 자실체 메탄올 추출물 DPPH 라디칼 소거 활성은 $0.125 \sim 2.0 \mathrm{mg} / \mathrm{mL}$ 농도 범위에서 양성대조군으로 사용한 BHT에 비해 전 농도 구간에서 활성이 조금 낮았으나 $1.0 \mathrm{mg} / \mathrm{mL}$ 와 2.0 $\mathrm{mg} / \mathrm{mL}$ 농도에서 각각 $90 \%$ 이상으로 소거 활성이 매우 높았다. 본 실험 결과 노랑느타리의 자실체를 3 종류의 용매를 이용해 추출한 물질을 $5 \mathrm{mg} / \mathrm{mL}$ 로 희석한 농도에서 확인한 DPPH 라디칼 소거활 성 46.6 68.4\%에 비해서 크게 높았으며 Alam 등(2011)이 보고한 새송이 자실체의 메탄올과 열수 추출물의 $2 \mathrm{mg} / \mathrm{mL}$ 농도에서의 $\mathrm{DPPH}$ 소거능 88.46\%와 84.45\%에 비해 신령버섯 메탄올 추출물 의 DPPH 소거 활성은 이미 보고된 다른 식용버섯과 비교해 크게 높 거나 또는 유사한 것으로 나타났다.

철 이온이 식물이나 미생물의 추출물에 의해 제거되는 기본 원 리는 이들 생물체의 추출물에 함유되어 있는 항산화 성분이 $\mathrm{Fe}^{2+}$ 이 온을 제거하여 더 이상 ferrozine- $\mathrm{Fe}^{2+}$ 복합체를 형성하지 못하는 것에 기인하는 것이다. 신령버섯 추출물의 철 이온 제거 활성은 $0.125 \sim 2.0 \mathrm{mg} / \mathrm{mL}$ 의 모든 실험 농도에서 양성대조군인 BHT에 비해 크게 높았다.

본 실험 결과는 Mau 등(2004)과 Tsai 등(2006)이 보고한 버들송 이와 잎새버섯 자실체의 열수추출물 $20 \mathrm{mg} / \mathrm{mL}$ 의 농도에서 나타 난 철 이온 제거능 $87.5 \%$ 와 $45.8 \%$ 에 비해서 높아서 신령버섯의 철 이온 제거 항산화효과는 버들송이와 팽이에 비해 우수한 것으로 나 타났다.

신령버섯의 자실체 추출물은 동일한 농도에서 양성대조군에 환 원력이 크게 떨어지는 것으로 나타났으나 추출물의 농도를 증가시 킴에 따라 환원력은 비례해서 증가하는 것으로 나타났다. Mau 등 (2004)은 잎새버섯의 자실체 메탄올 추출물 $5 \mathrm{mg} / \mathrm{mL}$ 의 농도에서 환원력이 0.37 이었다고 보고했는데 이 수치는 본 실험의 $4 \mathrm{mg} / \mathrm{mL}$ 의 추출물 환원력 1.142에 비해 낮았다. Alam 등(2012)은 아위버 섯 자실체의 메탄올과 열수추출물의 환원력이 $4.0 \mathrm{mg} / \mathrm{mL}$ 농도에 서 각각 1.078 과 0.802 를 나타낸다고 보고하여 동일한 농도에서 신령버섯의 메탄올 추출물 농도의 환원력에 비해 조금 낮게 나타났 다. 따라서 신령버섯 자실체의 메탄올 추출물의 환원력은 양성대조 군인 BHT에 비해서 낮았지만 잎새버섯이나 아위버섯의 환원력에 비해서는 높았다. $\alpha$-amylase는 탄수화물인 전분이나 글리코겐 등의 $\alpha-\mathrm{D}-(1,4)-$ glucan 결합을 분해하는 가수분해 효소로 탄수화물을 포도당, 맥 아당, 덱스트린 등으로 전환한다. 다음 단계의 효소에 의해 체내에 흡수되기 쉬운 형태의 포도당으로 분해되어 생물체는 이를 에너지 원으로 이용해 살아갈 수 있다. 그러나 이러한 분해 효소들이 과도 하게 작용하면 혈액내의 당이 급격하게 상승하게 되면서 당뇨와 비 만 등의 질병이 유발될 수 있다. 따라서 이러한 성인병의 예방과 치 료를 위해 전분의 분해에 중요한 역할을 하는 $\alpha$-amylase와 $\alpha$-glucosidase와 같은 효소의 활성을 조절하고 제어할 필요성이 있다(Lee 등, 2010). 본 실험에서 신령버섯 추출물의 $\alpha$-amylase에 대한 저해 활성은 양성대조군으로 사용한 acarbose에 비해 모든 실험농도에서 낮았으나 $1.0 \sim 2.0 \mathrm{mg} / \mathrm{mL}$ 농도에서 $60 \%$ 이상으로 나타나이 버섯의 자실체를 섭취하면 초기단계의 당뇨병 예방에 도 움이 될 수 있을 것으로 사료된다. $\alpha$-glucosidase는 $\alpha$-amylase가 탄수화물을 가수분해하여 맥아당 및 덱스트린 등으로 전환한 물질 을 작은창자에서 바로 흡수가 가능한 포도당으로 전환 시키는 가수 분해하는 소화효소이다. 본 실험에서 양성대조군으로 사용한 acarbose는 당뇨 2형의 환자에 처방되는 $\alpha$-amylase와 $\alpha$-glucosidase의 저해 활성이 매우 높은 경구투여제로 방선균인 $A C^{-}$ tinoplanes sp. 균주의 발효를 통해 생산되고 있다. Acarbose가 경 구 투여되면 흡수된 탄수화물의 소화와흡수가 지연되어 체내의 급 격한 혈당의 상승을 지연시켜 당뇨병을 완화시키는 효과가 나타나 는 것으로 보고되어 있다(Mahmud 등, 1999). 본 실험 결과 신령버 섯 자실체의 메탄올 추출물은 $0.125 \sim 1.0 \mathrm{mg} / \mathrm{mL}$ 범위의 농도에 서 양성대조군인 acarbose에 비해 저해 활성이 조금 높았으나 2.0 $\mathrm{mg} / \mathrm{mL}$ 의 농도에서만 저해 활성이 조금 낮았다.

$\mathrm{NO}$ 는 염증유발에 중요한 역할을 하는 활성산소종의 하나로 iNOS (nitric oxide synthase)에 의해 L-arginine으로부터 생성된 다. 본 실험에서는 세포 염증 유발 실험에 가장 많이 사용되는 LPS 를 처리한 RAW 264.7 세포에서의 NO 생성에 대한 신령버섯 자실 체의 메탄올 추출물의 저해효과를 측정하였다. 실험 결과, 추출물 을 투여한 RAW 264.7 세포군에서의 NO 생성량은 미처리군에 비 해 급격하게 낮아지는 경향이 나타나는 것으로 확인 되었다. Nguyen 등(2013)은 흰망태버섯 자실체의 메탄올 추출물을 2 $\mathrm{mg} / \mathrm{mL}$ 농도로 처리한 실험군의 $\mathrm{NO}$ 의 발생은 $81.2 \%$ 대폭 감소한 다고 보고하여 본 실험에서의 $\mathrm{NO}$ 감소량에 비해 저해효과가 높았 다. Kang (2012)에 의하면 팽이버섯 열수추출물을 RAW 264.7 세 포에 처리한 후 $1 \mu \mathrm{g}$ 의 LPS를 처리하였을 때 $\mathrm{NO}$ 의 생성량은 유의 성 있게 저해되었으며, $\mathrm{NO}$ 생성량은 추출물의 농도 증가에 따라 농 도 의존적으로 비례하여 감소한다고 보고하였다. 본 실험에서도 신 령버섯 추출물의 처리농도가 높아짐에 따라 RAW 264.7 세포내에 
서의 $\mathrm{NO}$ 의 생성량도 점차 감소하여 앞에서의 보고와 유사한 경향 을 보였다.

따라서 본 실험을 통해 신령버섯의 자실체 추출물에는 항산화 효과를 나타내는 폴리페놀, 당뇨병의 치료에 이용되는 $\alpha$-amylase 와 $\alpha$-glucosidase 저해물질, 그리고 염증을 저해하는 물질을 함유 하고 있는 것으로 나타났으나 이들 추출물의 효과를 좀 더 실용적 으로 규명하기 위해서는 생쥐나 쥐 등의 동물을 이용한 실험이 진 행되어야 할 것으로 사료되었다.

\section{요 약}

신령버섯(Agaricus brasilliensis)는 식용과 약용으로 사용되고 있는 담자균류에 속하는 버섯이다. 본 연구에서는 신령버섯의 자실 체를 메탄올과 열수를 이용해 추출한 물질의 항산화, 항당뇨 및 nitric oxide 생성 저해 효과에 대한 실험을 수행하였다. 고속액체 크로마토그래피를 이용해 이 버섯 자실체 추출물의 페놀성 화합물 을 분석한 결과 gallic acid, procatechuic acid, chlorogenic acid, (-)-epicatechin, vanillin, rutin hydrate, naringin, quercetin, formononetin, biochanin-A 등 총 10종류의 페놀성 화합물이 확인되었다. 항산화 효과 실험에서 메탄올 추출물의 DPPH radical 소거능은 양성대조군으로 사용한 BHT에 비해 낮았 지만 비교적 효과가 우수하였으며, 철 이온 제거 항산화 효과는 메 탄올 추출물이 양성대조군인 BHT에 비해 모든 실험 농도에서 유의 성 있게 높았다. 환원력의 경우 이 버섯의 추출물은 양성대조군에 비해 모두 모든 농도에서 효과가 낮게 나타났다. 항당뇨 실험에서 $\alpha$-glucosidase에 대한 메탄올추출물의 저해효과는 $1.0 \mathrm{mg} / \mathrm{mL}$ 와 $2.0 \mathrm{mg} / \mathrm{mL}$ 의 농도에서 각각 $54.48 \%$ 와 $78.43 \%$ 를 보여 양성대조 군인 acarbose의 $51.77 \%$ 과 $81.81 \%$ 에 비해 조금 낮았다. 염증저 해 효과 실험에서 RAW 264.7 대식세포가 배양되고 있는 배지에 신 령버섯 자실체의 메탄올과 열수추출물을 각각 전 처리 한 후 염증 매개 물질인 LPS를 투여하여 메탄올과 열수 추출물의 NO 생성 저 해효과를 조사한 결과 추출물의 농도가 증가함에 따라 대식세포에 생성된 NO의 양이 감소하는 경향을 나타내어 높은 농도에서 저해 효과가 우수한 것으로 나타났다. 따라서 신령버섯의 자실체에는 항 산화, 항당뇨, 및 항염증 효과를 나타내는 천연물질이 함유되어 있 어서 이를 섭취할 경우 건강에 유용한 것으로 생각되었다.

Acknowledgement: None

Funding: None

Conflict of intereat: None

\section{References}

1. Alam N, Yoon KN, Lee KR, Lee JS, Lee TS. Phenolic compounds concentration and appraisal of antioxidant and antioxidant and antityrosinase activities from the fruiting bodies of Pleurotus eryngii. Adv Environ Biol. 2011, 5:1104-1113.

2. Blois MS. Antioxidant determination by the use of a stable free radical. Nature. 1958, 181:1199-1200.

3. Carvajal AE, Koehnlein EA, Soares AA, Eler GJ, Nakashima ATA, Bracht A, et al. Bioactives of fruiting bodies and submerged culture mycelia of Agaricus brasiliensis (A. blazei) and their antioxidant properties. LWT-Food Sci Technol. 2012, 46:493-499.

4. Gulcin I, Buyukokuroglu ME, Oktay M, Kufrevioglu OI. Antioxidant and analgesic activities of turpentine of Pinus nigra Arn. subsp. pallsiana (Lamb.) Holmboe. J. Ethnopharmacol. 2003, 86;51-58.

5. Kang HW. Antioxidant and anti-inflammatory effects of extracts from Flammulina velutipes (Curtis) Singer. J Kor Soc Food Nut. 2012. 41:1072-1078.

6. Kim MY, Seguin P, Ahn JK, Kim JJ, Chun SC, Kim EH, et al. Phenolic compound concentration and antioxidant activities of edible and medicinal mushrooms from Korea. J Agric Food Chem. 2008, 56:7265-7270.

7. Kim HS, Kim TW, Kim DJ, Lee JS, Kim KK, Choe M. Antioxidant activities and $\alpha$-glucosidase inhibitory effect of water extracts from medicinal plants. Korean J Med Crop Sci. 2013, 21(3): 197-203.

8. Lee YL, Yen M, Mau JL. Antioxidant properties of various extracts from Hypsizigus marmoreus. Food Chem. 2007b, 104: $1-9$.

9. Lee SJ, Song, EJ, Kim KBWR, Lee CJ, Jung JY, Kwak JH, et al. Inhibitory Effects of Sargassum thunbergii ethanol extract against $\alpha$-amylase. Kor J Fish Aquat Sci. 2010, 43(6):648-653.

10. Lee HJ, Do JR, Jung SK, Kim HK. Physiological properties of Sarcodon aspratus extracts by ethanol concentration. J Kor Soc Food Sci Nutr. 2014, 43(5):656-660.

11. Mahmud, T, Tornus I, Egelkrout E, Woif E, Uy C, Floss HG, et al. Biosynthetic studies on the $\alpha$-glucosidase inhibitor acarbose in Actinoplanes sp.; 2-epi-5-epi-valiolone is the direct precursor of the valienamine moiety. I Amer Chem SOC. 1999, 121: 6973-6983.

12. Mau JL, Chang CN, Huang SJ, Chen CC. Antioxidant properties of methanolic extracts from Grifola frondosa, Morchella esculenta, and Termitomyces albuminosus mycelia. Food Chem. 2004. 87:111-118.

13. Mizuno T. Medicinal properties and clinical effects of culinary medicinal mushroom Agaricus blazei Murrill (Agaricomycetidae). Int J Med Mushrooms. 2002, 4:299-312.

14. Mosmann T. Rapid colorimetric assay for cellular growth and survival: application to proliferation and cytotoxicity assays. Immunol Meth. 1983, 65:55-63.

15. Nguyen TK, Shin DB, Lee KR, Shin PG, Cheong JC, Yoo YB, et al. Antioxidant and anti-inflammatory activities of fruiting bodies of Dyctiophora indusiata. J Mushroom Sci Prod. 2013, 11(4): 269-277.

16. Prasad NK, Divakar S, Shivamurthy GR, Aradhya SM. Isolation of a free radical scavenging antioxidant from water spinach 
(Ipomoea aquatica Forsk). J Sci Food Agri. 2005, 85:1461-1468.

17. Ryu JH, Ahn H, Kim, JY, Kim, YK. Inhibitory activity of plant extracts on nitric oxide synthesis in LPS-activated macrophage. Phytother Res. 2003, 17:485-489

18. Shim SM, Im KH, Lee UY, Kim JW, Shim MJ, Lee MW, et al. Studies on immuno-modulatory and antitumor effects of crude polysaccharides extracted from Paecilomyces sinclairii. Kor J Mycol. 2003, 31:155-160.

19. Tsai SY, Huang SJ, Mau JL. Antioxidant properties of hot water extracts from Agrocybe cylindracea. Food Chem. 2006, 98:670-677.
20. Um SN, Jin GE, Park KW, Yu YB, Park KM. Physiological activity and nutritional composition of Pleurotus species. Kor J Food $S C i$ Technol. 2010, 42(1):90-96.

21. Wasser SP, Weis AL. Medicinal properties of substances occurring in higher basidiomycete mushrooms: current perspectives (Review). Internat. J Med Mushrooms. 1999, 1:31-62

22. Worthington, editors. Worthington enzyme manual. 1993. p36-261. Worthington Biochemical Corp., Freehold.

23. Yena GC, Duhb PD, Tsaia L. Antioxidant and pro-oxidant properties of ascorbic acid and gallic acid. Food Chem. 2002, 79:307-313. 